\title{
Article
}

http://dx.doi.org/10.11646/phytotaxa.174.1.2

\section{Overlooked diversity in Brazilian Cypella (Iridaceae, Iridoideae): four new taxa from the Río de la Plata grasslands}

\author{
OLIVIER CHAUVEAU ${ }^{1, *}$, TAMARA PASTORI ${ }^{2}$, TATIANA T. SOUZA-CHIES ${ }^{1,2} \&$ LILIAN EGGERS ${ }^{1,2}$ \\ ${ }^{1}$ Departamento de Botânica, Universidade Federal do Rio Grande do Sul, Av. Bento Gonçalves, 9500, CEP 91501-970, Porto Alegre, \\ Rio Grande do Sul, Brazil; e-mail: oli.chauveau@laposte.net \\ ${ }^{2}$ Programa de Pós-Graduação em Botânica, Universidade Federal do Rio Grande do Sul, Av. Bento Gonçalves, 9500, CEP 91501-970, \\ Porto Alegre, Rio Grande do Sul, Brazil. \\ "author for correspondence
}

\begin{abstract}
Three new species and one subspecies of Cypella are described for Rio Grande do Sul (RS), Brazil: Cypella altouruguaya from northern RS, C. amplimaculata widely distributed across the state and C. rivularis restricted to southern RS, in grassland streams of the Pampa biome. Cypella hauthalii subsp. minuticristata is found in a central area of Rio Grande do Sul. The different taxa are described, illustrated and compared with related species. The resulting taxonomic framework shows that most of the species described for Cypella occur in the Río de la Plata grasslands, with various infrageneric taxa characterised by a high level of endemism, especially in the Subtropical Grasslands of Southern Brazil.
\end{abstract}

Key words: Campos eco-region, endemism, Rio Grande do Sul, Subtropical Grasslands, taxonomy

\section{Introduction}

Iridaceae is divided into seven subfamilies and comprise about 2030 species distributed among 65 to 75 genera (Goldblatt et al. 2008). The Iridoideae, with more than 900 species, represent one of the two major evolutionary branches of the family and make up about $44 \%$ of the species richness of the Iridaceae (Goldblatt \& Manning 2008). Among the five tribes of this subfamily, the New World tribe of Tigridieae forms a monophyletic lineage of about 15 genera and 160 species (Goldblatt \& Manning 2008, Chauveau et al. 2012). Cypella Herbert (1826: t. 2637), with 30 species and four subspecies accepted by the World Checklist of Iridaceae (WCI), is one of two largest genera of the tribe in South America (Goldblatt \& Manning 2008, Barker 2014). The taxonomic delimitation of this genus phylogenetically closely related to Calydorea and Herbertia remains controversial (Chauveau et al. 2012, Deble et al. 2012). Indeed, among the species accepted by the WCI in Cypella, three species present the distinctive morphological features of Phalocallis Herbert (1839: t. 3710): C. boliviana Huaylla (2012: 297), C. geniculata (Klatt 1871: 517) Ravenna (1964: 53 ) and C. oreophila Spegazzini (1917: 44). The former species is considered morphologically strictly related to the type species of Phalocallis, P. coelestis (Lehmann 1826: 17) Ravenna (1977: 9) and is only distinguished by small variations of floral traits (Huaylla \& Wood 2012). Cypella geniculata and C. oreophila were included by Ravenna (2009) in Phalocallis based on the same distinctive floral traits than the type species of the genus. Furthermore, the latest comprehensive phylogeny of Tigridieae confirmed that Phalocallis should be regarded as a separate genus from Cypella (Chauveau et al. 2012). The resulting circumscription of Cypella shows that $80 \%$ of the species and subspecies are found in the Río de la Plata grasslands (RPG), one of the most extensive biogeographic units of the grassland biome in the world (Medan et al. 2011). Indeed, this is the largest complex of subtropical and temperate grassland ecosystems in South America (Soriano et al. 1992, Miñarro \& Bilenca 2008). These grasslands include the eco-regions of Pampas in North Eastern Argentina, and the Campos eco-regions in Uruguay, Northern Argentina, South East Paraguay and Southern Brazil, where most of the Cypella species are distributed (Di Giacomo \& Krapovickas 2005, Overbeck et al. 2007, Paruelo et al. 2007). In Southern Brazil, the grassland vegetation is included in two separate biomes according to the current official classification (IBGE 2004): the Pampa and the Atlantic Forest (Overbeck et al. 2007). The RPG is perhaps one of the regions in the world with highest rates of land use and land cover changes related to human activities 
more than $85 \%$ of the taxa currently described for the genus occur in the Río de la Plata grasslands, $80 \%$ are endemic to this biogeographic unit and 65\% are only found in the Campos eco-region, mainly in the state of Rio Grande do Sul (Southern Brazil) where 14 species and two subspecies are presently registered. These observations suggest that the centre of diversity of Cypella is located in the Río de la Plata grasslands, mostly in the subtropical Campos grasslands, and that local endemism is not uncommon at the infrageneric level.

\section{Acknowledgements}

The authors are grateful to Marcela Padilha Longhi for the preparation of herbarium specimens and to Anelise Scherer for the illustrations of the taxa habits. We are also indebted to Juliana Fachinetto and Bethânia Azambuja who provided the geographic location of two different populations of $C$. hauthalii subsp. minuticristata. The first author received a post-doctoral fellowship (process 503118/2011-7) granted by the Conselho Nacional de Desenvolvimento Científico e Tecnológico (CNPq) and the second author was sponsored by a masters scholarship (ed. MCT/CNPq/MEC/ CAPES 52/2010) provided by the Programa de Capacitação em Taxonomia (PROTAX/process 562261/2010-9).

\section{References}

Barker, C. (2014) World Checklist of Iridaceae. Facilitated by the Royal Botanic Gardens, Kew. Published on the Internet: http://apps.kew. org/wcsp/ (accessed 13 March 2014).

Beentje, H. (2010) The Kew Plant Glossary: an illustrated dictionary of plant terms. Royal Botanic Gardens, Kew, 160 pp.

Chauveau, O., Eggers, L., Souza-Chies, T.T. \& Nadot, S. (2012) Oil-producing flowers within the Iridoideae (Iridaceae): evolutionary trends in the flowers of the New World genera. Annals of Botany (London) 110: 713-729.

http://dx.doi.org/10.1093/aob/mcs134

Deble, L.P., Oliveira-Deble, A.S. \& Alves, F.S. da (2012) Two new species of Cypella (Iridaceae: Tigridieae) from Rio Grande do Sul, Brazil. Phytotaxa 71: 59-68.

Di Giacomo, A.S. \& Krapovickas, S. (2005) Conserving the grassland important bird areas (IBAs) of southern South America: Argentina, Uruguay, Paraguay, and Brazil. In: Ralph, C.J. \& Rich, T.D. (Eds.) Bird Conservation Implementation and Integration in the Americas: Proceedings of the Third International Partners in Flight Conference 2. United States Department of Agriculture, Forest Service, Albany, pp. 1243-1249.

Eggers, L. (2014) Cypella In: Lista de Espécies da Flora do Brasil. Jardim Botânico do Rio de Janeiro. Published on the Internet: http:// floradobrasil.jbrj.gov.br/jabot/floradobrasil/FB36319/ (accessed 24 March 2014).

Foster, R.C. (1950) Studies in the Iridaceae VI. Contributions from the Gray Herbarium of Harvard University 171: 22-28.

Goldblatt, P. \& Manning, J.C. (2008) The Iris Family: natural history and classification. Timber Press, Portland, 290 pp.

Goldblatt, P., Rodriguez, A., Powell, M.P., Davies, T.J., Manning, J.C., Van der Bank, M. \& Savolainen, V. (2008) Iridaceae “out of Australasia"? Phylogeny, Biogeography, and Divergence time based on plastid DNA sequences. Systematic Botany 33: 495-508. http://dx.doi.org/10.1600/036364408785679806

Herbert, W. (1826) Tigridia Herberti supra N²599. Cypella. Curtis’s Botanical Magazine 53: t. 2637.

Herbert, W. (1839) Phalocallis plumbea lead-coloured Phalocallis. Curtis's Botanical Magazine 65 (n. ser. v. 12): t. 3710.

Herbert, W. (1840) Alophia. Curtis's Botanical Magazine 66 (n. ser. v. 13): t. 3779.

Hauman-Merck, L. (1909) Cypella nova argentina. Apuntes de Historia Natural 1: 84-86.

Huaylla, H. \& Wood, J.R.I. (2012) Cypella boliviana (Iridaceae), a new species from Bolivia. Kew Bulletin 67: 1-4. http://dx.doi.org/10.1007/s12225-012-9401-5

Iganci, J.R.V., Heiden, G., Miotto, S.T.S. \& Pennington, R.T. (2011) Campos de Cima da Serra: the Brazilian Subtropical Highland Grasslands show an unexpected level of plant endemism. Botanical Journal of the Linnean Society 167: 378-393. http://dx.doi.org/10.1111/j.1095-8339.2011.01182.x

Instituto Brasileiro de Geografia e Estatística (IBGE) (2004) Mapa da vegetação do Brasil e Mapa de Biomas do Brasil. Published on the Internet: http://www.ibge.gov.br/ (accessed 20 February 2014).

IUCN (2001) The IUCN Red List of Threatened Species, version 2010.4. IUCN Red List Unit, Cambridge U.K. Available from: http:// www.iucnredlist.org (accessed: 3 February 2014).

Klatt, F.G. (1871) Irideae In: Martius, C.F.P.von \& Eichler, A.G. (Eds.) Flora Brasiliensis 3(1). Wolf, C. et fil. \& Minsinger, S., Munich, pp. 510-548. 
Kuntze, O. (1898) Iridaceae. Revisio Generum Plantarum 3: 304-309.

http://dx.doi.org/10.5962/bhl.title.327

Lehmann, J.G.C. (1826) Semina in Horto Botanico Hamburgensi 1826 collecta. Meissneri, J.G., Hamburg, 18 pp.

Lindley, J. (1826) Moraea Herberti. The Botanical Register 11: t. 949.

Marco, E.G., Tacuatiá, L.O., Eggers, L., Santos, E.K. \& Souza-Chies, T.T. (2009) Genetic variability within Cypella fucata Ravenna in Southern Brazil. In: Mahoney, C.L. \& Springer, D.A. (Eds.) Genetic Diversity. Nova Publishers Inc., Nova York, pp. $179-194$.

Medan, D., Torretta, J.P., Hodara, K., De la Fuente, E.B. \& Montaldo, N.H. (2011) Effects of agriculture expansion and intensification on the vertebrate and invertebrate diversity in the Pampas of Argentina. Biodiversity and Conservation 20: 3077-3100. http://dx.doi.org/10.1007/s10531-011-0118-9

Miñarro, F. \& Bilenca, D. (2008) The conservation status of temperate grasslands in Central Argentina. Special Report. Fundación Vida Silvestre Argentina, Buenos Aires, 25 pp.

Overbeck, G.E., Müller, S.C., Fidelis, A., Pfadenhauer, J., Pilar, V.D., Blanco, C.C., Boldrini, I.I., Both, R. \& Forneck, E.D. (2007) Brazil’s neglected biome: the south Brazilian Campos. Perspectives in Plant Ecology, Evolution and Systematics 9: 101-116. http://dx.doi.org/10.1016/j.ppees.2007.07.005

Paruelo, J.M., Jobbágy, E.G., Oesterheld, M., Golluscio, R.A. \& Aguiar, M.R. (2007) The grasslands and steppes of Patagonia and the Rio de la Plata plains. In: Veblen, T., Young, K. \& Orme, A. (eds.). The Physical Geography of South America. The Oxford Regional Environments Series. Oxford University Press, Oxford, pp. 232-248.

Ravenna, P. (1964) Notas sobre Iridaceae. Revista del Instituto Municipal de Botanica 2: 51-60.

Ravenna, P. (1965) Notas sobre Iridaceae II. Boletin de la Sociedad Argentina de Botanica 10: 311-322.

Ravenna, P. (1968) Iridaceae. In: Cabrera, A.L. Flora de la Provincia de Buenos Aires 4(1). Instituto Nacional de Tecnología Agropecuaria, Buenos Aires, Argentina, pp. 539-565.

Ravenna, P. (1977) Notas sobre Iridaceae V. Noticário Mensual Museo Nacional História Natural 21: 7-9.

Ravenna, P. (1981a) Eight new species and two new subspecies in the genus Cypella (Iridaceae). Wrightia 7: 13-22.

Ravenna, P. (1981b) A submerged new species of Cypella (Iridaceae) and a new section for the genus (s.str.). Nordic Journal of Botany 1: 489-492.

http://dx.doi.org/10.1111/j.1756-1051.1981.tb00714.x

Ravenna, P. (2009) A survey in the genus Cypella and its allies. Onira, Botanical Leaflets 12: 1-10.

Rusby, H.H. (1896) An enumeration of the plants collected in Bolivia by Miguel Bang - III. Memoirs of the Torrey Botanical Club 6: $1-130$.

Soriano, A., León, R.J.C., Sala, O.E., Lavado, R.S., Deregibus, V.A., Cahuepé, O., Scaglia, A., Velazquez, C.A. \& Lemcoff, J.H. (1992) Río de la Plata grasslands. In: Coupland, R.T. (Ed.) Ecosystems of the World. Natural Grasslands. Introduction and Western Hemisphere. Elsevier, Amsterdam, pp. 367-407.

Spegazzini, C. (1917) Ramillete de plantas argentinas nuevas o interesantes. Physis 3(13): 37-46.

Vega, E., Baldi, G., Jobbágy, E.G. \& Paruelo, J. (2009) Land use change patterns in the Río de la Plata grasslands: the influence of phytogeographic and political boundaries. Agriculture, Ecosystems and Environment 134: 287-292.

http://dx.doi.org/10.1016/j.agee.2009.07.011

Velloso, J.M.C. (1827) Florae Fluminensis Icones 9. Parisiis ex off. lithogr. Senefelder, Paris, 130 pp. 